\title{
Xylanase (GH11) from Acremonium cellulolyticus: homologous expression and characterization
}

\author{
Masahiro Watanabe, Hiroyuki Inoue*, Benchaporn Inoue, Miho Yoshimi, Tatsuya Fujii and Kazuhiko Ishikawa*
}

\begin{abstract}
Cellulosic materials constitute most of the biomass on earth, and can be converted into biofuel or bio-based materials if fermentable sugars can be released using cellulose-related enzymes. Acremonium cellulolyticus is a mesophilic fungus which produces a high amount of cellulose-related enzymes. In the genome sequence data of A. cellulolyticus, ORFs showing homology to $\mathrm{GH} 10$ and $\mathrm{GH} 11$ xylanases were found. The xylanases of $A$. cellulolyticus play an important role in cellulolytic biomass degradation. Search of a draft genome sequence of $A$. cellulolyticus for xylanase coding regions identified seven ORFs showing homology to $G H 11$ xylanase genes $(x y|A, x y| B, x y / C, x y|D, x y| E, x y \mid F$ and $x y \mid G)$. These genes were cloned and their enzymes were prepared with a homologous expression system under the control of a glucoamylase promoter. Six of the seven recombinant enzymes were successfully expressed, prepared, and characterized. These enzymes exhibited optimal xylanase activity at pH 4.0 - 4.5. But this time, we found that only XylC had enormously higher relative activity $\left(2947 \mathrm{U} \cdot \mathrm{mg}^{-1}\right)$ than the other xylanases at optimum $\mathrm{pH}$. This result is surprising because XylC does not retain a carbohydrate-binding module $1(\mathrm{CBM}-1)$ that is necessary to bind tightly own substrate such as xylan. In this study, we discuss the relationship between activity, $\mathrm{pH}$ and sequence of seven xylanases in A. cellulolyticus.
\end{abstract}

Keywords: Acremonium cellulolyticus; Xylanase; Hemicellulose; Homologous expression; Biomass; Xylan

\section{Introduction}

Lignocellulosic biomass can be converted into biofuel or bio-based materials (Deutschmann and Dekker 2012; Kumar et al. 2008) but must be converted into fermentable sugars by saccharification. Xylan is one of the major structural components of plant cell walls and is the second most abundant renewable biomass resource (York and O'Neill 2008). Xylan consists of a backbone of $\beta-1,4-D$-xylan with short side chains of O-acetyl, $\beta$-L-arabinofuranosyl, D- $\alpha$ glucuronic acid and phenolic acid (Coughlan and Hazlewood 1993). Xylanases (endo-1,4- $\beta$-xylanases; EC 3.2.1.8) catalyze the hydrolysis of the $\beta-1,4$ bonds of xylan and thus are important enzymes for the degradation of hemicellulosic polysaccharides (Collins et al. 2005; Prade 1996). Based on their amino acid sequence similarities, xylanases are mainly classified into families 10 and 11 of the glycoside hydrolases (GH; http://www.cazy.org/Glycoside-Hydrolases.html; (Coutinho and Henrissat 1999). GH10 xylanases

\footnotetext{
* Correspondence: inoue-h@aist.go.jp; kazu-ishikawa@aist.go.jp Biomass Refinery Research Center, National Institute of Advanced Industrial Science and Technology (AIST), 3-11-32 Kagamiyama, Higashi-Hiroshima,
} Hiroshima 739-0046, Japan generally have a molecular weight $\geq 30 \mathrm{kDa}$ and a low $\mathrm{p} I$, while GH11 xylanases are generally smaller (approximately $20 \mathrm{kDa}$ ) and have a high $\mathrm{p} I$ (Beaugrand et al. 2004). The crystal structures of xylanases show that GH10 enzymes fold into a $(\beta / \alpha)_{8}$-barrel (Dimarogona et al. 2012; Harris et al. 1994; Lo Leggio et al. 1999), whereas family 11 enzymes have a $\beta$-jellyroll structure (Paës et al. 2012; Sidhu et al. 1999). Cellulose and xylan are closely linked together in plant cell walls (Carpita and Gibeaut 1993). Thus, cellulases and hemicellulases work coordinately in the enzymatic degradation of these polysaccharides.

Filamentous fungi produce a wide spectrum of degradation enzymes for cellulose and xylan (van den Brink and de Vries 2011). Acremonium cellulolyticus, isolated by Yamanobe et al., is a high cellulolytic enzyme-producing fungus (Yamanobe et al. 1987). Fujii et al. reported that the culture supernatant from A. cellulolyticus has a higher cellulase specific activity and yields more glucose from lignocellulosic materials than the culture supernatant from Trichoderma reesei (Fujii et al. 2009). Thermostable xylanase from $A$. cellulolyticus was found by Mitsuishi et al. (Mitsuishi et al. 1987), but this enzyme has not been 
identified. Furthermore, there is no report of the expression and characterization of the xylanases (GH11) from A. cellulolyticus. The cellulose-induced xylanases of $A$. cellulolyticus play an important role in the cellulolytic biomass degradation process. In this study, we searched the xylanase coding regions from the draft genome sequence of A. cellulolyticus (unpublished data) and attempted to clarify the characteristics of the all xylanases (GH11).

\section{Materials and Methods Materials}

Birch-wood xylan was purchased from Sigma-Aldrich (St. Louis, MO, USA). All other chemicals were of the highest grade commercially available.

Strain and culture conditions for Acremonium cellulolyticus Acremonium cellulolyticus CF-2612 and Y-94 (CBS136886) were maintained on potato dextrose agar plates (Fang et al. 2009). The A. cellulolyticus YP-4 uracil autotroph was maintained on potato dextrose agar plates containing uracil and uridine at final concentrations of $1 \mathrm{~g} / \mathrm{l}$ each (Inoue et al. 2013). Transformants of A. cellulolyticus YP-4 were maintained on MM agar plates (Fujii et al. 2012). For measurement of gene expression, the strains were cultivated in $50 \mathrm{ml}$ of basic medium $(24 \mathrm{~g} / \mathrm{l}$ of $\mathrm{KH}_{2} \mathrm{PO}_{4}, 1 \mathrm{~g} / \mathrm{l}$ of Tween 80, $5 \mathrm{~g} / \mathrm{l}$ of $\left(\mathrm{NH}_{4}\right)_{2} \mathrm{SO}_{4}, 1.2 \mathrm{~g} / \mathrm{l}$ of $\mathrm{MgSO}_{4} \bullet 7 \mathrm{H}_{2} \mathrm{O}, 0.01 \mathrm{~g} / \mathrm{l}$ of $\mathrm{ZnSO}_{4} \bullet 7 \mathrm{H}_{2} \mathrm{O}, 0.01 \mathrm{~g} / \mathrm{l}$ of $\mathrm{MnSO}_{4} \bullet 6 \mathrm{H}_{2} \mathrm{O}, 0.01 \mathrm{~g} / \mathrm{l}$ of $\mathrm{CuSO}_{4} \bullet 7 \mathrm{H}_{2} \mathrm{O}$; pH 4.0) supplemented with $20 \mathrm{~g} / \mathrm{l}$ soluble starch (Wako Pure Chemical Industries, Osaka, Japan) as a carbon source in 500-ml Erlenmeyer flasks at $30^{\circ} \mathrm{C}$ for $96 \mathrm{~h}$ on a rotary shaker operated at $230 \mathrm{rpm}$. The cells were centrifuged for $15 \mathrm{~min}$ at 3,500 rpm, then the supernatants were centrifuged for $10 \mathrm{~min}$ at $13,500 \mathrm{rpm}$. The pooled enzyme solution was filtered through a $0.45 \mu \mathrm{M}$ membrane and adjusted with acetate buffer ( $\mathrm{pH}$ 5.0) containing $0.01 \%$ $\mathrm{NaN}_{3}$. The samples were stored at $4^{\circ} \mathrm{C}$ until use.

\section{Cloning of xylanases and construction of the expression vector}

A draft genome sequence of $A$. cellulolyticus (unpublished data) was searched for the xylanase (GH11) genes using In silico Molecular Cloning gene analysis software (In Silico Biology, Inc., Yokohama, Japan) based on the internal amino acid sequence. Construction of the xylanase expression vector for A. cellulolyticus basically followed a procedure described previously (Inoue et al. 2013). The genomic regions encoding xylanases were amplified by PCR from CF-2612 chromosomal DNA using primers as indicated in Table 1 . The seven amplified xylanase genes were constructed by introducing the appropriate fragment digested with $H p a \mathrm{I} / S b f l(x y l A, x y l B, x y l C, x y l D$, $x y l E$ and $x y l F)$ into the EcoRV/Sbfl $(x y l G)$ site of a series of pANC expression vectors containing a glucoamylase
Table 1 Summary of nucleotide primers used in this study

\begin{tabular}{|c|c|}
\hline Primer & Nucleotide sequence $\left(5^{\prime} \rightarrow 3^{\prime}\right)$ \\
\hline \multicolumn{2}{|l|}{$\begin{array}{l}\text { For plasmids } \\
\text { construction }\end{array}$} \\
\hline AC-F12 (xy/A) & ATTGTTAACAAGATGAAGATCACATCAGTGTTCG \\
\hline AC-R12 (xy|A) & AATCCTGCAGGTTAAGATACAGTAACAGTGGCACTTC \\
\hline AC-F13 $(x y \mid B)$ & ATTGTTAACATCATGGGCATCTCATCTATTCTTC \\
\hline AC-R13 $(x y \mid B)$ & AATCCTGCAGGCTATTGGCACTGACTGTAGTAAGCGT \\
\hline AC-F25 (xylC) & ATTGTTAACAAGATGAAGCTCTCTCTGGCTGCAA \\
\hline AC-R25 (xy/C) & AATCCTGCAGGCTAGGACACGGTGATGGTACTAGAAC \\
\hline AC-F26 (xyID) & ATTGTTAACAAGATGCGGTCATTTGCTCGCCTTGTC \\
\hline AC-R26 (xylD) & AATCCTGCAGGTCAGCTAACAGTAAAATCCAGGTAAC \\
\hline AC-F27 (xylE) & ATTGTTAACAAGATGATTTATTTCCCTCAGCTCATG \\
\hline AC-R27 (xylE) & AATCCTGCAGGCTATTGAGTGGCAGTCTGCTGGGCA \\
\hline AC-F28 (xy/F) & ATTGTTAACAAGATGTTCTCTTTCAGTACTGCCTT \\
\hline AC-R28 (xy/F) & AATCCTGCAGGCTACAAGCATTGATAGTAGTACGGGT \\
\hline AC-F29 $(x y / G)$ & ATTGATATCAAGATGGTTGCTITCTCGAGCTTATTTAC \\
\hline AC-R29 (xy/G) & AATCCTGCAGGGTCCAACATCAATGCTACTTACAGC \\
\hline \multicolumn{2}{|c|}{ For quantitative $P C R$} \\
\hline$x y / A-f$ & GAGGACGGAGTCAATGGAGA \\
\hline$x y \mid A-r$ & CCGAGAGGTAGGAGCCAGAA \\
\hline$x y / B-f$ & TGCTCTCGGTGTTGATGTTG \\
\hline$x y \mid B-r$ & GTGGTCTGGTAGTCGGTGGA \\
\hline$x y / C-f$ & GTGTCGACCAACCCTCCATC \\
\hline$x y / C-r$ & GTCCAAGTGCCTTCCATGCT \\
\hline$x y / D-f$ & TITAGCGATAGCGGCAGGTT \\
\hline$x y / D-r$ & CCCATGTAAGGGAGCGAGTT \\
\hline$x y \mid E-f$ & CGGGCCACAAACTATATCCA \\
\hline$x y \mid E-r$ & TTCCAGCCAACACCAACAAC \\
\hline$x y \mid F-f$ & ACTAGCAAGGACGGCGTAGA \\
\hline$x y \mid F-r$ & CACCGAGGAACTCAGACGAA \\
\hline$x y / G-f$ & CAGCACGGGGTTTGAGGTT \\
\hline$x y / G-r$ & CCGAAGTTGATGGGAGTGGT \\
\hline$g p d A-f$ & AACATCATTCCCAGCAGCAC \\
\hline$g p d A-r$ & CGGCAGGTCAAGTCAACAAC \\
\hline
\end{tabular}

(glaA) promoter and terminator (Inoue et al. 2013): pANC209 ( $x y l A)$, pANC210 ( $x y l B)$, pANC223 $(x y l C)$, pANC230 ( $x y l D)$, pANC231 $(x y l E)$, pANC232 $(x y l F)$ and pANC233 ( $x y l G)$ (Table 2).

\section{Homologous expression of the recombinant xylanases}

Protoplasts of $A$. cellulolyticus YP-4 were transformed with pANC209, 210, 223, 230, 231, 232 and 233 by nonhomologous integration into the host chromosomal DNA (Fujii et al. 2012). Gene integration into prototrophic transformants was verified by genomic PCR. The expression of each recombinant xylanase was carried out using the 
Table 2 Summary of seven xylanases (GH11) in A. cellulolyticus

\begin{tabular}{lllllll}
\hline Strain & Plasmid & Xyl11 & AA & MW (Da) & CBM-1 & N-terminal sequence (5 aa) \\
\hline Y209 & pANC209 & A & 209 & 22377 & - & AGGIN \\
Y210 & pANC210 & B & 282 & 29510 & CBM & AEAIN \\
Y223 & pANC223 & C & 223 & 23955 & - & QSITT \\
Y230 & pANC230 & D & 190 & 21029 & - & - \\
Y231 & pANC231 & E & 234 & 25788 & - & ATNYI \\
Y232 & pANC232 & F & 276 & 29210 & CBM & NTPNS \\
Y233 & pANC233 & G & 233 & 24906 & - & SAINY \\
\hline
\end{tabular}

following cultures: Y209 (YP-4 transformed with pANC209; XylA), Y210 (YP-4 transformed with pANC210; XylB), Y223 (YP-4 transformed with pANC223; XylC), Y230 (YP-4 transformed with pANC230; XylD), Y231 (YP-4 transformed with pANC231; XylE), Y232 (YP-4 transformed with pANC232; XylF), Y233 (YP-4 transformed with pANC233; XylG) (Table 2). All cultures were grown in medium containing $20 \mathrm{~g} / \mathrm{l}$ soluble starch and $5 \mathrm{~g} / \mathrm{l}$ urea using the method described previously (Inoue et al. 2013). The recombinant xylanases expressed were purified from the culture supernatant.

\section{Purification of the recombinant xylanases}

A. cellulolyticus Y209, 210, 223, 231, 232 and 233 were grown at $30^{\circ} \mathrm{C}$ on a starch-induced medium. The purification procedures were basically as previously reported (Lee et al. 2009). The purified enzyme was concentrated, dialyzed against $20 \mathrm{mM}$ sodium acetate buffer ( $\mathrm{pH}$ 5.0) using a Vivaspin 20 concentrator (10,000 MWCO, Sartorius AG, Goettingen, Germany) and stored at $4^{\circ} \mathrm{C}$ until use. The purity and size of the protein was analyzed by SDS-PAGE using precast NuPAGE 4 - 12\% polyacrylamide Bis-Tris gels (Life Technologies, Carlsbad, CA, USA) (Hachmann and Amshey 2005). All proteins were identified by $\mathrm{N}$-terminus sequence analysis.

\section{Protein assay}

Protein concentration was determined by a Pierce BCA Protein Assay Kit (Pierce, Rockford, IL, USA) using bovine serum albumin as the standard (Shibuya et al. 1989; Smith et al. 1985). Protein solution $(25 \mu \mathrm{l})$ was mixed with $200 \mu \mathrm{l}$ of $\mathrm{BCA}$ reagent and then incubated at $37^{\circ} \mathrm{C}$ for $30 \mathrm{~min}$. Protein concentration was determined by measuring the absorption at $570 \mathrm{~nm}$.

\section{$\mathrm{N}$-terminus sequence analysis}

The N-terminal sequences of six xylanases (XylA, XylB, $\mathrm{XylC}$, XylE, XylF and XylG) were commercially determined by Edman degradation using Procise 494 HT (ABI, Foster City, California, USA). Each enzyme was adjusted to $2.0 \mathrm{mg} / \mathrm{ml}(600 \mu \mathrm{g})$ in $20 \mathrm{mM}$ sodium acetate buffer (pH 5.5) prior to degradation.

\section{Enzyme assay}

The xylanase activity assay was based on the method described by Bailey et al. (1992), using 1\% (w/v) birchwood xylan (Sigma-Aldrich) as the substrate. Activity was examined under a variety of buffer conditions between pH 3.0 and 8.0 (McIlvaine 1921). The appropriately diluted protein solution was mixed with $0.45 \mathrm{ml}$ of substrate, followed by incubation for $10 \mathrm{~min}$ at $50^{\circ} \mathrm{C}$. The reducing sugars produced in the reaction mixture were measured by a 3,5-dinitrosalicylic acid (DNS) assay. One unit of xylanase activity was defined as the quantity of enzyme required to liberate $1 \mu \mathrm{mol}$ of xylose equivalent per minute at $50^{\circ} \mathrm{C}$.

\section{Differential scanning fluorimetry (DSF)}

A series of DSF experiments generally followed the protocol published by Niesen and others (Niesen et al. 2007; Lo et al. 2004). The experiments were carried out with a CFX96 Real-Time PCR System ${ }^{\text {"w }}$ (Bio-Rad) using 450/490 excitation and 560/580 emission filters in a 96-well plate format. Each enzyme was prepared at a final concentration of $0.1 \mathrm{mg} / \mathrm{ml}(2 \mu \mathrm{g})$ in $50 \mathrm{mM}$ sodium acetate $\mathrm{pH} 4.0$ buffer. SYPRO orange dye [5,000-fold stock solution in dimethyl sulfoxide (DMSO); Invitrogen, Carlsbad, CA, USA] was added in twentyfold dilution to the enzyme (Senisterra and Finerty 2009). The negative control comprised buffer and the SYPRO mixture, without xylanase. Each sample $(20 \mu \mathrm{l}$ per well) was measured between 25 and $90^{\circ} \mathrm{C}$ using a stepwise gradient of $0.5^{\circ} \mathrm{C}$ per $5 \mathrm{~s}$. Following curve fitting of the data to the Boltzmann equation, the melting temperature $(T m)$ of each xylanase was calculated using Bio-Rad CFX Manager software (Bio-Rad). The results are shown in Table 3.

\section{Real-time quantitative PCR}

Total RNA was extracted from disrupted fungal cells. Single-stranded cDNA was synthesized and then realtime quantitative PCR was conducted as described previously (Fujii et al. 2010). The expression of each gene was normalized against that of the glyceraldehyde-3phosphate dehydrogenase gene (gpdA accession number AB847425). Results are shown as relative expressions. 
Table 3 Specific activity and thermal shift assay of six xylanases (GH11)

\begin{tabular}{|c|c|c|c|c|c|}
\hline $\begin{array}{l}\text { Enzyme } \\
\text { (GH11) }\end{array}$ & $\begin{array}{l}\text { Specific } \\
\text { activity at } \\
\text { pH } 5.5(\mathrm{U} / \mathrm{mg})\end{array}$ & $\begin{array}{l}\text { Specific activity } \\
\text { at optimum } \\
\text { pH (U/mg) }\end{array}$ & $\begin{array}{l}\mathrm{Tm}\left({ }^{\circ} \mathrm{C}\right) \\
\text { at } \mathrm{pH} 5.5\end{array}$ & $\begin{array}{l}\mathrm{Tm}\left({ }^{\circ} \mathrm{C}\right) \\
\text { at optimum } \\
\mathrm{pH}\end{array}$ & $\Delta^{\circ} \mathrm{C}$ \\
\hline XylA & 320 & $999(\mathrm{pH} 4.0)$ & 55 & 59 & 4 \\
\hline XylB & 252 & $667(\mathrm{pH} 4.0)$ & 62.5 & 66 & 3.5 \\
\hline Xylc & 1434 & $2947(\mathrm{pH} 4.0)$ & 58 & 61.5 & 3.5 \\
\hline XylE & 43 & 304 (pH 4.0) & 59 & 65.5 & 6.5 \\
\hline XylF & 16 & $34(\mathrm{pH} 4.0)$ & 54 & 60 & 6 \\
\hline XylG & 35 & $285(\mathrm{pH} 4.0)$ & 55 & 64.5 & 9.5 \\
\hline
\end{tabular}

The gene-specific primers used were shown in Table 1. The nucleotide sequences of each gene from CF-2612 will appear in the GenBank/EMBL/DDBJ nucleotide database under accession nos. AB847990 (xylA), AB847991 ( $x y l B), \mathrm{AB} 847992(x y l C), \mathrm{AB} 847993$ ( $x y l D), \mathrm{AB} 847994$ $(x y l E), \mathrm{AB} 847995$ ( $x y l F)$, and AB847996 ( $x y l G)$.

\section{Results}

\section{Cloning of xylanase genes from A. cellulolyticus}

A search of the genome sequence database of $A$. cellulolyticus identified seven ORFs exhibiting homology to xylanase (GH11) genes: $x y l A$ (689 bp), $x y l B$ (915 bp), $x y l C$ (735 bp), xylD (845 bp), xylE (760 bp), $x y l F(952 \mathrm{bp)}$ and $x y l G$ (761 bp). The PCR-amplified DNA fragments were ligated into the expression vectors containing a glucoamylase $(g l a A)$ promoter and terminator, as described in Materials and Methods. All ligated gene fragments and their ligation sites were verified by sequencing. The $x y l D$ gene was found to be smaller than the other xylanase genes (Figure 1) and the speculative conserved active site residue (Glu) near the C-terminus of xylanase was absent.

\section{Homologous expression and purification of the recombinant xylanases}

For $x y l A, x y l B, x y l C, x y l D, x y l E, x y l F$ and $x y l G$ genes, the homologous expression vector (pANC209, 210, 223, 230, 231, 232 and 233, respectively) was transformed into A. cellulolyticus YP-4 to provide Y209, Y210, Y223, Y230, Y231, Y232 and Y233 (Table 2). SDS-PAGE analysis showed that the molecular size of XylA $(22.3 \mathrm{kDa})$, XylB (29.5 kDa), XylC (23.9 kDa), XylE (25.7 kDa), XylF $(29.2 \mathrm{kDa})$ and XylG (24.9 kDa) was in accordance with the molecular size calculated from the individual sequences (Figure 2). XylD activity was not detetcted in this expression system because of its incomplete length (Figure 1). Presumably the higher molecular masses of XylB and XylF are largely due to the presence of a CBM-1 with each catalytic domain (Figure 2).

\section{Comparison of sequence identity and $\mathrm{N}$-terminal sequence analysis}

The deduced amino acid sequence of the ORFs indicated that XylA, XylB, XylC, XylD, XylE, XylF and XylG are encoded by 209, 282, 223, 190, 234, 276 and 233 amino acids, respectively, including the individual signal peptides at the $\mathrm{N}$-terminus. Table 2 shows the five $\mathrm{N}$-terminal amino acids of each expressed xylanase. In this homologous expression system, these signal peptides were cleaved off by a signal peptidase on the $\mathrm{N}$-terminal side of the arginine residue. Both $\mathrm{XylB}$ and XylF include a carbohydrate-binding module (CBM-1) at their C-terminus. Figure 1 shows a sequence alignment of the active domain in the xylanases. Six xylanases (XylA, XylB, XylC, XylE, XylF and XylG) exhibit amino acid sequence homology of around $11 \sim 52 \%$, with the two catalytic glutamates being strictly conserved.

Specific activity and the effect of $\mathrm{pH}$ on xylanase activity Xylanase activity assays were carried out using 1\% (w/v) birch-wood xylan under a variety of buffer conditions between $\mathrm{pH} 3.0$ and 8.0. Calculation of the specific activity of each xylanase showed that XylC has much higher specific activity, ranging from about 4.5 to 90-fold higher than the other xylanases at pH 5.5 (Table 3). The optimum $\mathrm{pH}$ of all the xylanases is between $\mathrm{pH} 4.0-4.5$, although XylA and $\mathrm{XylC}$ retain activity between $\mathrm{pH} 4.0-$ 6.0 and $\mathrm{pH} 4.0$ - 7.0, respectively (Figure 3). XylC exhibited twofold higher activity at its optimum $\mathrm{pH}(\mathrm{pH} 4.0)$ than at $\mathrm{pH} 5.5$.

\section{Thermostability of the xylanases}

Fluorescence-based thermal shift assays of the xylanases were performed in a 96-well plate format using a realtime PCR detection system and a volume of $20 \mu \mathrm{l}$ per well. The samples were heated at $0.1^{\circ} \mathrm{C} / \mathrm{s}$ from 25 to $90^{\circ} \mathrm{C}$. All the xylanases were found to be thermostable between 52 and $61^{\circ} \mathrm{C}$ at $\mathrm{pH} 5.5$, and their thermostability increased by 4 to $10^{\circ} \mathrm{C}$ at $\mathrm{pH} 4.0$ (Table 3). These results show that all xylanases are in a more active and thermostable form at $\mathrm{pH} 4.0$.

\section{Gene expression in cultures grown on cellulose and xylan}

A. cellulolyticus Y-94 was cultured on Solka Floc or xylan as the carbon source for 24, 72, and $120 \mathrm{~h}$, then the levels of expression of their xylanase gene were measured by real-time quantitative PCR (Figure 4). No expression of any xylanase gene was observed after $24 \mathrm{~h}$ under both growth conditions (undetectable). A higher expression level of $x y l A$ and $x y l B$ was observed in $72 \mathrm{~h}$, indicating that these genes contribute to xylan degradation by $A$. cellulolyticus. $x y l C$, which showed the highest xylanase activity, was expressed slightly compared with $x y l A$ and $x y l B$; the expression of $x y l D, x y l E, x y l F$ and $x y l G$ was not detected 
under any of the conditions tested, with the exception of $x y l G$ at $120 \mathrm{~h}$, xylan cultivation. Figure 4 shows the expression levels relative to that of $g p d A$ used as an internal control.

\section{Discussion}

Analysis of the A. cellulolyticus genome identified seven ORFs exhibiting homology to the xylanase (GH11) genes: $x y l A, x y l B, x y l C, x y l D, x y l E, x y l E$ and $x y l G$, which encode XylA (209 aa), XylB (282 aa), XylC (223 aa), XylD (190 aa), XylE (234 aa), XylF (276 aa) and XylG (233 aa), respectively. Each gene also encodes the signal peptide at the $\mathrm{N}$ terminus. N-terminal sequence analysis showed that each signal peptide is cleaved by an aminopeptidase N-terminal to the arginine residue in this homologous expression system (Inoue et al. 2013). In addition, Blast alignments indicated that only XylB and XylF have a carbohydratebinding module (CBM-1) at their C-terminus, suggesting that XylB and XylF bind more strongly to their substrate than the other xylanases. Figure 1 shows the sequence alignment of the active domain in the xylanases. Six xylanases (XylA, XylB, XylC, XylE, XylF and XylG) exhibit amino acid sequence homology of around $11 \sim 52 \%$ and strictly conserve the two catalytic glutamate residues, and also strongly conserve other resides located in the speculative catalytic cleft (Paës et al. 2012). Although the structure of XylC or any of the other xylanases has not been determined, it is expected to have a $\beta$-jellyroll structure based on multiple sequence alignment and molecular weight analyses. This protein folding motif is extremely common in small molecular weight $(<30 \mathrm{kDa})$ proteins like the GH11 family (Paës et al. 2012). Analysis of the 


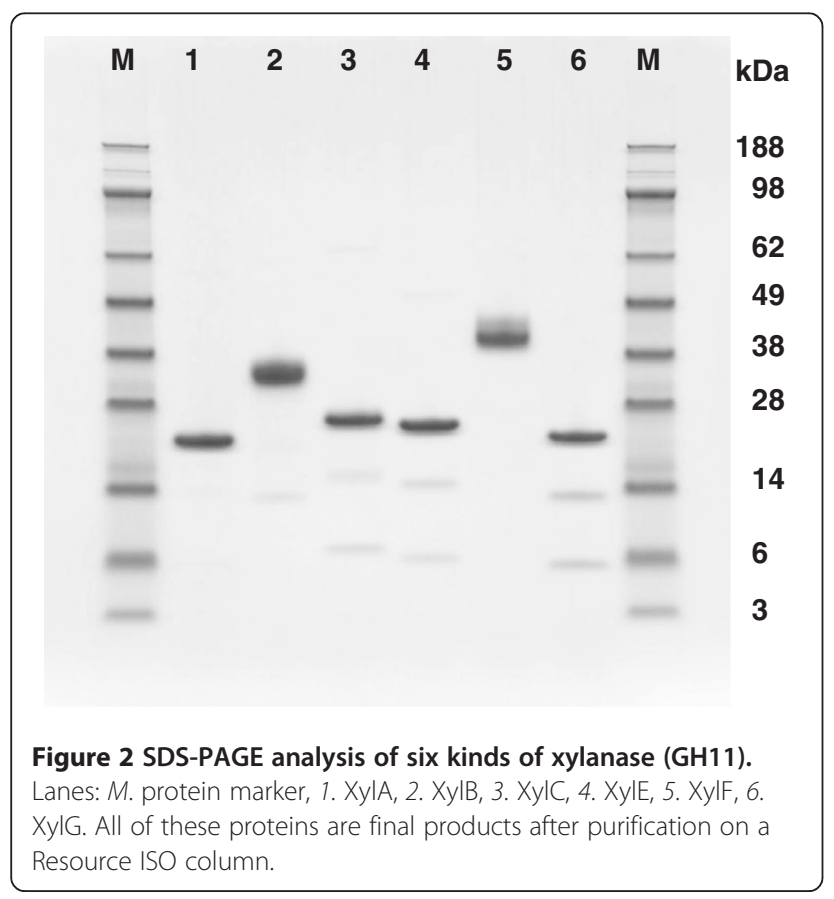

A. cellulolyticus genome showed the $x y l D$ gene to be smaller than the other family members (Figure 1), and that it lacks some of the regions conserved in the other xylanases, including one of the catalytic glutamic acids. It seems that the $x y l D$ gene cannot translate normal xylanase protein $(\mathrm{XylD})$ in A. cellulolyticus. Amino acid sequence alignments suggest that the active domains of six xylanases (Xyl11A, B, C, E, F, and G) in A. cellulolyticus have common activity and structure, and share high homology with the GH11 family of Trichoderma reesei, which is well known for its hyper-productivity (Zou et al. 2012). There is over $50 \%$ sequence identity between $\mathrm{XylC}$ and $T$. reesei GH11.

Six of the seven xylanases (Xyl11A, B, C, E, F, and G) were expressed and purified successfully in A. cellulolyticus transformant strains. SDS-PAGE analysis shows that the purified XylB, XylE, XylF and XylG are accompanied by one or two smaller, faint bands (Figure 2). However, these proteins exhibited the significant xylanase activity toward the birch-wood xylan (Bailey et al. 1992). Therefore, their faint bands suggest the nick regions of the recombinant proteins expressed. The nick regions seem to be located somewhere in these folded proteins (unclear). The $\mathrm{N}$-terminus of the expressed protein giving rise to each major band was also determined (Table 2). These data indicate that $A$. cellulolyticus efficiently translates and expresses these xylanase genes using this homologous expression system (Inoue et al. 2013).

Activity assays conducted at various $\mathrm{pH}$ values showed that all the xylanases have their optimum $\mathrm{pH}$ between $\mathrm{pH} 4.0-4.5$, although XylA and XylC retain activity between $\mathrm{pH} 4.0-6.0$ and $\mathrm{pH} 4.0-7.0$, respectively (Figure 3). In addition, we examined the specific activity of all the xylanases against xylan and found that XylC has much higher specific activity than the other xylanases

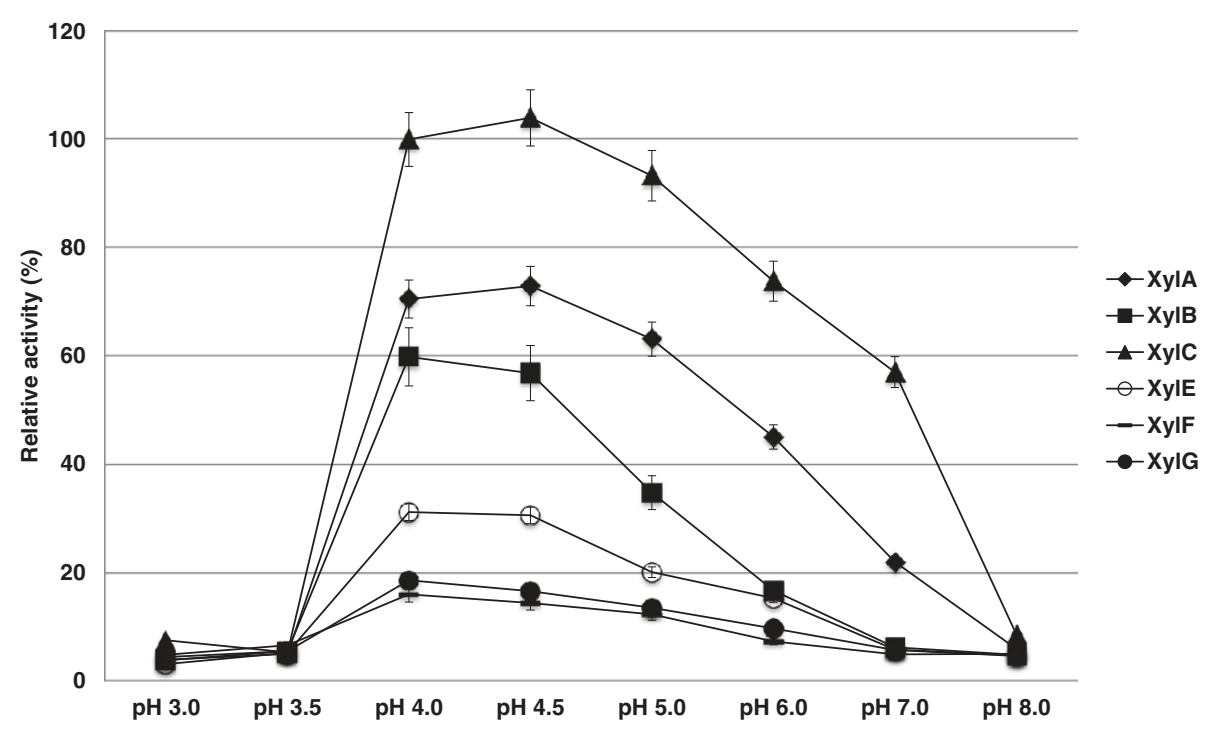

Figure 3 Optimum pH of six kinds of xylanase (GH11). The optimal pH of each xylanase was determined using the DNS method with $1 \%$ $(\mathrm{w} / \mathrm{v})$ birch-wood xylan. The buffers were: $0.1 \mathrm{M}$ citric acid buffer $\mathrm{pH} 3.0-3.5 ; 0.1 \mathrm{M}$ sodium acetate $\mathrm{pH}$ 4.0 - 4.5; $0.1 \mathrm{M}$ sodium citrate $\mathrm{pH}$ 5.0 - 6.0; 0.1 M Hepes-NaOH pH 7.0; 0.1 M Tris-HCl pH 8.0. The enzymes are: XylA (black diamond), XylB (black square), XylC (black triangle), XylE (white circle), XyIF (black dash) and XylG (black circle). The percent relative activity is based on the activity of XylC at pH 4.0. The data plotted are averages of triplicate experiments. 

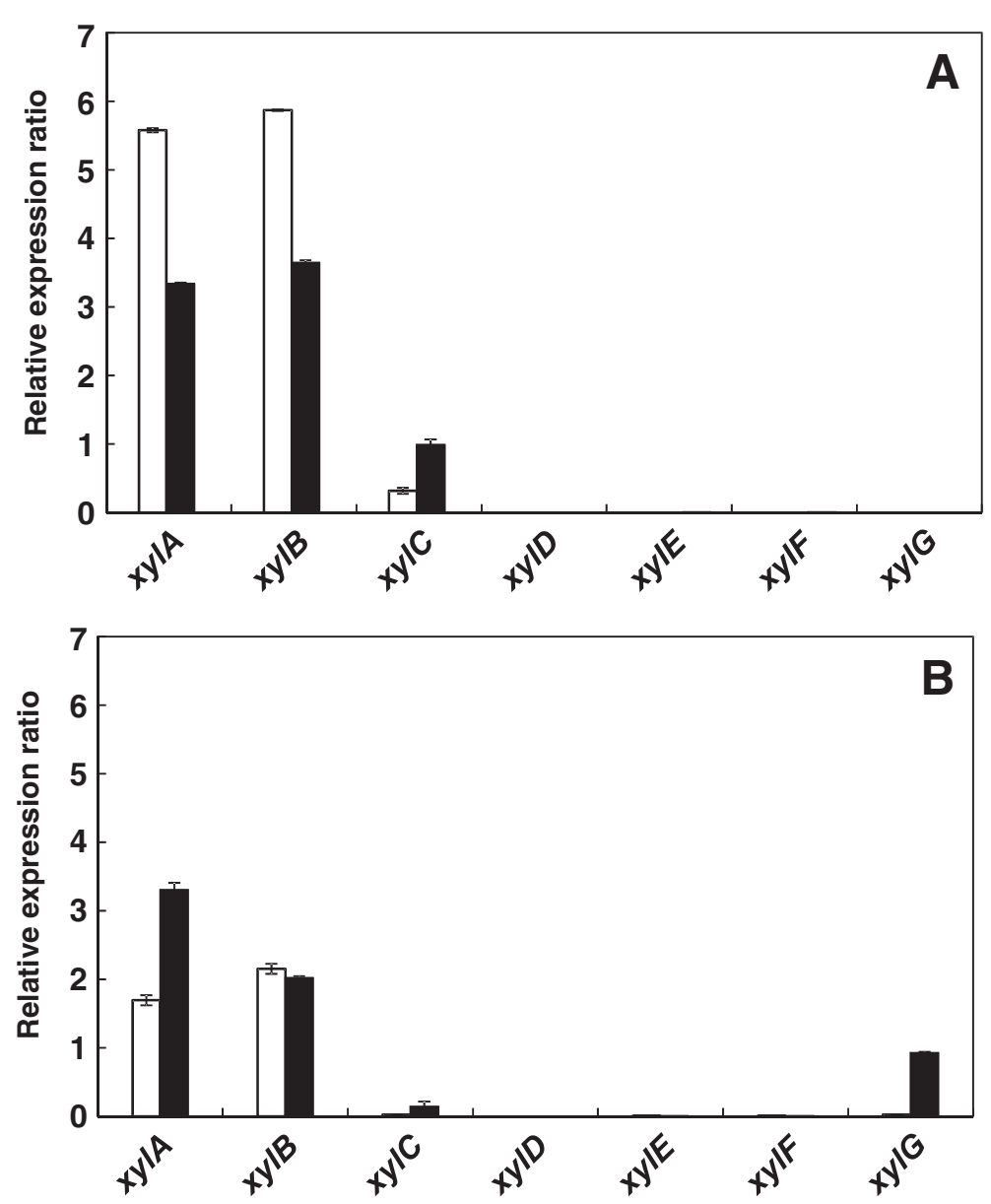

Figure 4 Expression of xylanase genes. A. cellulolyticus Y-94 was cultured in medium containing $50 \mathrm{~g} / \mathrm{l}$ of cellulose (A) or $50 \mathrm{~g} / \mathrm{l}$ of xylan (B). Culture time was $24 \mathrm{~h}$ (data not shown), $72 \mathrm{~h}$ (white bars), and $120 \mathrm{~h}$ (black bars). Expression levels are shown relative to that of $g p d A$ as an internal control.

(Table 3). XylC exhibited between 4.5 to 90 -fold higher activity at $\mathrm{pH} 5.5$ than the other xylanases, and twofold higher activity at its optimum $\mathrm{pH}(\mathrm{pH} 4.0)$ than at $\mathrm{pH}$ 5.5. These results clearly show that XylC plays the important role as a glycoside hydrolase 11 (GH11) of all the xylanases in A. cellulolyticus. It is possible that XylC uses a different mechanism for substrate recognition and catalysis compared to other xylanases. Detailed structural studies will be required to clarify this issue.

The levels of expression of the seven xylanase genes in Y-94 cultured for 24,72 , and $120 \mathrm{~h}$ were measured by real-time quantitative PCR (Figure 4). No expression of any xylanase gene was observed after $24 \mathrm{~h}$ (data not shown). A higher expression level of $x y l A$ and $x y l B$ was observed compared to the other xylanases, indicating that these genes contribute to xylan degradation by $A$. cellulolyticus after $72 \mathrm{~h} . X y l C$, which showed the highest xylanase activity, was expressed slightly less than $x y l A$ and $x y l B$. This result suggests that expression of $x y l A$ and $x y l B$ is important for the saccharification of biomass, and that the detailed substrate specificity of $x y l A$ and $x y l B$ may be different from that of $x y l C$. The expression of $x y l D, x y l E, x y l F$ and $x y l G$ was not detected under any of the conditions tested, with the exception of $x y l G$ at $120 \mathrm{~h}$, xylan cultivation (Figure 4).

Thermal shift assays conducted using differential scanning fluorimetry showed that the xylanases have a $T_{m}$ of around $60^{\circ} \mathrm{C}$ at $\mathrm{pH} 5.5$, and that their thermostability increases by up to $10^{\circ} \mathrm{C}$ at $\mathrm{pH} 4.0$ (Table 3). These results show that all GH11s in A. cellulolyticus are most stable and active at $\mathrm{pH}$ 4.0. Industrial use of this enzyme will require thermostability at least up to $70^{\circ} \mathrm{C}$. XylC plays an important role in degrading xylan and is a good candidate for industrial use in food, paper and chemical production (Deutschmann and Dekker 2012; Polizeli et al. 2005). We are currently attempting to crystallize $\mathrm{XylC}$ to determine its atomic-level structure by $\mathrm{X}$-ray crystallography.

\section{Competing interests}

The authors declare that they have no competing interests. 


\section{Acknowledgements}

This work was supported by the Japan-U.S. Cooperation Project for Research and Standardization of Clean Energy Technologies.

Received: 4 December 2013 Accepted: 7 January 2014 Published online: 01 April 2014

\section{References}

Bailey MJ, Biely P, Poutanen K (1992) Interlaboratory testing of methods for assay of xylanase activity. J Biotechnol 23:257-270, doi:10.1016/0168-1656(92)90074-J

Beaugrand J, Chambat G, Wong V, Goubet F, Rémond C, Paës G, Benamrouche S, Debeire P, O'Donohue M, Chabbert B (2004) Impact and efficiency of GH10 and $\mathrm{GH} 11$ thermostable endoxylanases on wheat bran and alkali-extractable arabinoxylans. Carbohydr Res 339:2529-2540, doi:10.1016/j.carres.2004.08.012

Carpita NC, Gibeaut DM (1993) Structural models of primary-cell walls in flowering plants - consistency of molecular-structure with the physical-properties of the walls during growth. Plant J 3:1-30, doi:10.1111/j.1365-313X.1993.tb00007.x

Collins T, Gerday C, Feller G (2005) Xylanases, xylanase families and extremophilic xylanases. FEMS Microbiol Rev 29:3-23, doi:10.1016/j.femsre.2004.06.005

Coughlan MP, Hazlewood GP (1993) Beta-1,4-D-xylan-degrading enzyme-systems biochemistry, molecular-biology and applications. Biotechnol Appl Biochem 17:259-289, doi:10.1111/j.1470-8744.1993.tb00244.x

Coutinho PM, Henrissat B (1999) Carbohydrate-active enzymes: an integrated database approach. Roy Soc Ch 246:3-12

Deutschmann R, Dekker RF (2012) From plant biomass to bio-based chemicals: latest developments in xylan research. Biotechnol Adv 30:1627-1640, doi:10.1016/j.biotechadv.2012.07.001

Dimarogona M, Topakas E, Christakopoulos P, Chrysina ED (2012) The structure of a GH10 xylanase from Fusarium oxysporum reveals the presence of an extended loop on top of the catalytic cleft. Acta Crystallogr D 68:735-742, doi:10.1107/S0907444912007044

Fang X, Yano S, Inoue H, Sawayama S (2009) Strain improvement of Acremonium cellulolyticus for cellulase production by mutation. J Biosci Bioeng 107:256-261, doi:10.1016/j.jbiosc.2008.11.022

Fujii T, Fang X, Inoue H, Murakami K, Sawayama S (2009) Enzymatic hydrolyzing performance of Acremonium cellulolyticus and Trichoderma reesei against three lignocellulosic materials. Biotechnol Biofuels 2:24, doi:10.1186/1754-6834-2-24

Fujii T, Murakami K, Sawayama S (2010) Cellulase hyperproducing mutants derived from the fungus Trichoderma reesei QM9414 produced large amounts of cellulase at the enzymatic and transcriptional levels. Biosci Biotechnol Biochem 74:419-422, http://dx.doi.org/10.1271/bbb.90655

Fujii T, Iwata K, Murakami K, Yano S, Sawayama S (2012) Isolation of uracil auxotrophs of the fungus Acremonium cellulolyticus and the development of a transformation system with the pyrF gene. Biosci Biotechnol Biochem 76:245-249, http://dx.doi.org/10.1271/bbb.110498

Hachmann JP, Amshey JW (2005) Models of protein modification in Tris-glycine and neutral pH Bis-Tris gels during electrophoresis: effect of gel pH. Anal Biochem 342:237-245, http://dx.doi.org/10.1016/j.ab.2005.04.015

Harris GW, Jenkins JA, Connerton I, Cummings N, Loleggio L, Scott M, Hazlewood GP, Laurie Jl, Gilbert HJ, Pickersgill RW (1994) Structure of the catalytic core of the family $F$ xylanase from Pseudomonas fluorescens and identification of the xylopentaose-binding sites. Structure 2:1107-1116

Inoue H, Fujii T, Yoshimi M, Taylor LE 2nd, Decker SR, Kishishita S, Nakabayashi M, Ishikawa K (2013) Construction of a starch-inducible homologous expression system to produce cellulolytic enzymes from Acremonium cellulolyticus. J Ind Microbiol Biotechnol 40:823-830, doi:10.1007/s10295-013-1286-2

Kumar R, Singh S, Singh OV (2008) Bioconversion of lignocellulosic biomass: biochemical and molecular perspectives. J Ind Microbiol Biotechnol 35:377-391, doi:10.1007/s10295-008-0327-8

Lee JW, JY P k, Kwon M, Choi IG (2009) Purification and characterization of a thermostable xylanase from the brown-rot fungus Laetiporus sulphureus. J Biosci Bioeng 107:33-37, doi:10.1016/j.jbiosc.2008.09.006

Lo Leggio L, Kalogiannis S, Bhat MK, Pickersgill RW (1999) High resolution structure and sequence of T. aurantiacus xylanase I: implications for the evolution of thermostability in family 10 xylanases and enzymes with (beta)alpha-barrel architecture. Proteins 36:295-306, doi:10.1002/(SICI) 1097-0134(19990815)36:3

Lo MC, Aulabaugh A, Jin GX, Cowling R, Bard J, Malamas M, Ellestad G (2004) Evaluation of fluorescence-based thermal shift assays for hit identification in drug discovery. Anal Biochem 332:153-159, http://dx.doi.org/10.1016/j. ab.2004.04.031
Mcllvaine TC (1921) A buffer solution for colorimetric comparison. J Biol Chem 49:183-186

Mitsuishi Y, Yamanobe T, Yagisawa M, Takasaki Y (1987) Purification and properties of thermostable xylanases from mesophilic fungus strain Y-94. Agric Biol Chem 51:3207-3213, http://dx.doi.org/10.1271/bbb1961.51.3207

Niesen FH, Berglund H, Vedadi M (2007) The use of differential scanning fluorimetry to detect ligand interactions that promote protein stability. Nat Protoc 2:2212-2221, doi:10.1038/nprot.2007.321

Paës G, Berrin JG, Beaugrand J (2012) GH11 xylanases: Structure/function/ properties relationships and applications. Biotechnol Adv 30:564-592, doi:10.1016/j.biotechadv.2011.10.003

Polizeli ML, Rizzatti AC, Monti R, Terenzi HF, Jorge JA, Amorim DS (2005) Xylanases from fungi: properties and industrial applications. Appl Microbiol Biotechnol 67:577-591, doi:10.1007/s00253-005-1904-7

Prade RA (1996) Xylanases: from biology to biotechnology. Biotechnol Genet Eng Rev 13:101-131

Senisterra GA, Finerty PJ Jr (2009) High throughput methods of assessing protein stability and aggregation. Mol Biosyst 5:217-223, doi:10.1039/b814377c

Shibuya T, Watanabe Y, Nalley KA, Fusco A, Salafsky B (1989) The BCA protein determination system. An analysis of several buffers, incubation temperature and protein standards. Tokyo Ika Daigaku Zasshi 47:677-682

Sidhu G, Withers SG, Nguyen NT, McIntosh LP, Ziser L, Brayer GD (1999) Sugar ring distortion in the glycosyl-enzyme intermediate of a family $\mathrm{G} / 11$ xylanase. Biochemistry 38:5346-5354, doi:10.1021/bi982946f

Smith PK, Krohn RI, Hermanson GT, Mallia AK, Gartner FH, Provenzano MD, Fujimoto EK, Goeke NM, Olson BJ, Klenk DC (1985) Measurement of protein using bicinchoninic acid. Anal Biochem 150:76-85, http://dx.doi.org/10.1016/ 0003-2697(85)90442-7

Thompson JD, Higgins DG, Gibson TJ (1994) CLUSTAL W: improving the sensitivity of progressive multiple sequence alignment through sequence weighting, position-specific gap penalties and weight matrix choice. Nucl Acids Res 22:4673-4680, doi:10.1093/nar/22.22.4673

van den Brink J, de Vries RP (2011) Fungal enzyme sets for plant polysaccharide degradation. Appl Microbiol Biotechnol 91:1477-1492, doi:10.1007/s00253011-3473-2

Yamanobe T, Mitsuishi Y, Takasaki Y (1987) Isolation of a cellulolytic enzyme producing microorganism, culture conditions and some properties of the enzymes. Agric Biol Chem 51:65-74

York WS, O'Neill MA (2008) Biochemical control of xylan biosynthesis - which end is up? Curr Opin Plant Biol 11:258-265, doi:10.1016/j.pbi.2008.02.007

Zou G, Shi S, Jiang Y, van den Brink J, de Vries RP, Chen L, Zhang J, Ma L, Wang C, Zhou Z (2012) Construction of a cellulase hyper-expression system in Trichoderma reesei by promoter and enzyme engineering. Microb Cell Fact 11:21, doi:10.1186/1475-2859-11-21

\section{doi:10.1186/s13568-014-0027-x}

Cite this article as: Watanabe et al:: Xylanase (GH11) from Acremonium cellulolyticus: homologous expression and characterization. AMB Express 2014 4:27.

\section{Submit your manuscript to a SpringerOpen ${ }^{\odot}$ journal and benefit from:}

- Convenient online submission

- Rigorous peer review

- Immediate publication on acceptance

- Open access: articles freely available online

- High visibility within the field

- Retaining the copyright to your article

Submit your next manuscript at $>$ springeropen.com 